\title{
Effect of Topography and Soil Depth on Clay Content, Organic Matter Content, Active Acidity, Reserve Acidity and Cation Exchange Capacity of Some Tea Soils of Bangladesh
}

\author{
A. F. M. Sanaullah ${ }^{1 *}$, M. Akhtaruzzaman ${ }^{2}$ and M. A. Uddin ${ }^{1}$ \\ ${ }^{1}$ Department of Chemistry, University of Chittagong, Chittagong-4331, Bangladesh \\ ${ }^{2}$ Department of Soil Science, University of Chittagong, Chittagong-4331, Bangladesh
}

Received 28 February 2016, accepted in final revised form 29 March 2016

\begin{abstract}
Soil samples were collected from M. R. Khan tea-estate area of Moulvibazar district, Bangladesh. Organic matter, active acidity, reserve acidity, cation exchange capacity, clay content and textural class of the collected soil samples for different topographic positions and depths were determined. The percentage of sand, silt and clay varied from 59.75 to $70.50,12.50$ to 20.00 and 14.50 to 22.75 , respectively. Active acidity and reserve acidity of the soils varied from 4.13 to 5.82 and 3.46 to 4.84 , respectively. Organic matter content varied from $0.37 \%$ to $1.93 \%$. Cation exchange capacity (CEC) varied from 11.42 to 24.86 $\mathrm{cmolKg}^{-1}$. Soils were acidic in nature with considerably high reserve acidity. The measured parameters of the soil samples were plotted and analyzed with reference to topography and depth. The parameters have been found to vary with sampling sites, depths and topography.

Keywords: Soil; Clay content; Active acidity; Reserve acidity; Cation exchange capacity.

๑) 2016 JSR Publications. ISSN: 2070-0237 (Print); 2070-0245 (Online). All rights reserved. doi: http://dx.doi.org/10.3329/jsr.v8i2.26867 J. Sci. Res. 8 (2), 229-235 (2016)
\end{abstract}

\section{Introduction}

Tea is the most widely consumed non-alcoholic drink in the world produced from Camellia sinensis. It is one of the cash crops in the world and Bangladesh is one of the tea exporting countries in the world. There are about 165 tea-estates in the country. The average per acre production of tea in Bangladesh is about $534 \mathrm{~kg}(1175 \mathrm{lbs})$, where the average yield of tea in the world is about 600-700 kg (1320-1543 lbs) per acre. The average yield of tea of the studied tea-estate is around $466.80 \mathrm{~kg}$ per acre. The proper growth of plants, like tea, jute, coffee etc. mainly depends on soil management, physicochemical properties and nutrient status of soil and their availability to plants [1-8]. However, the reproductivity as well as survival of microorganisms depends largely on

Corresponding author: $\underline{\text { sanaullahfazal@gmail.com }}$ 
active acidity, reserve acidity, buffer capacity and cation exchange capacity (CEC) of the soil [9-14]. Variation of soil properties and structures largely depend on various natural factors such as climate, topography, parent material and vegetation [15-17], of which topography is considered as one of the most important abiotic factors that controls the pedogenic processes on a local scale $[18,19]$. Data on such properties of tea soils of Bangladesh are scarce. Recently, we have reported the physico-chemical properties and major nutrient status of the soils of Rungicherra, Kaliti and Rangapani tea-estates of Moulvibazar and Chittagong District, Bangladesh respectively [20-23]. In this work, we are reporting the clay content, textural class, organic matter content, active acidity, reserve acidity and cation exchange capacity of soil along with the effect of topography and depths on the soil properties of M. R. Khan tea-estate of the Moulvibazar district.

\section{Materials and Methods}

Fifty-four (54) soil samples were collected from different sites of M. R. Khan tea-estate. The top-soil $(0-23 \mathrm{~cm})$, sub-soil $(23-46 \mathrm{~cm})$ and the substratum-soil $(46-91 \mathrm{~cm})$ of three different topographic positions (hill-top, hill-slope and hill-base) were collected in the month of January. The collected soil samples were dried in air at room temperature, crushed to $2 \mathrm{~mm}$ sieve and then analyzed.

\subsection{Methods}

Soil texture (percentage of sand, silt and clay content) was determined by the hydrometer (Model ERTCO 544416, ASTM, USA) method [24], soil organic carbon by wet-oxidation method [25] and organic matter content of the soil samples was calculated by multiplying the percent of organic carbon by Van Bemmelen factor, 1.73. The active acidity i.e., $\mathrm{pH}$ in water of the soil samples was determined by a $\mathrm{pH}$ meter (model HI 8424, HANNA Instruments, Romania) at the soil - water ratio of 1: 2.5 [26]. The reserve acidity i.e., $\mathrm{pH}$ in $0.1 \mathrm{M} \mathrm{CaCl}_{2}$ was measured by the same $\mathrm{pH}$ meter for the soil $-\mathrm{CaCl}_{2}(0.1 \mathrm{M})$ ratio of 1 : 2.5 [27]. Cation exchange capacity (CEC) was determined by using ammonium acetate method [28].

\subsection{Statistical analysis}

Values of different parameters were reported as the mean \pm standard deviation. Statistical analysis of the measured parameters was performed by using Origin Pro 7.0 version at the level of $\mathrm{p}<0.05$, to evaluate the significance of differences.

\section{Results and Discussion}

The data for sand, silt and clay content, organic matter content, active acidity, reserve acidity, and cation exchange capacity of the studied soils are listed in Table 1 and Table 2 
along with the standard deviations. Each data is the mean of eighteen measurements. Data on particle size distribution revealed that the percentage of sand, silt and clay of the experimental soils varied respectively, from $59.75 \sim 70.50,12.50 \sim 20.00$ and $14.83 \sim$ 19.71. Based on the particle size distribution of soil of the area, two different classes of soils, sandy loam (SL) and sandy clay loam (SCL) are identified. Noticeably maximum soils are found SL in nature. High sand content of the soils, as found here, allows good aeration and drainage, which is important for tea cultivation [29]. All these properties were found to vary with sampling sites as well as with topographic positions and depth. The percent of sand content of the soils of Rungicherra tea-estate varied from 55 to 76 with a mean value of 69 [20], while, the clay content varied from 16 to 33 percent. These variations of sand and clay are comparatively higher than those of studied tea-estate. On the other hand, Islam et al., [23] reported that the clay content of Rangapani tea-estate of Chittagong district varied from 11.0 to 43.5 percent. In the present studied tea-estate clay content follows a trend for topographic variations, i.e., Hill-top > Hill-slope > Hill-base. On the other hand, for different soil depths it follows the following sequence: Substratum soil $(46-91 \mathrm{~cm})>$ Top soil $(0-23 \mathrm{~cm})>$ Sub soil $(23-46 \mathrm{~cm})$ (Table 1 and 2$)$. The survival of microorganisms mainly depends on the soil organic matters and it is often called the life of the soil. A healthy soil should have a good number of many types of organisms. Commercial fertilizer cannot provide a food source for the soil microorganisms and it does not help the soil structure, aeration and porosity of the soil as organic matter does. Higher percentage of organic matter helps the plants to absorb water and nutrients more efficiently and thus increase the crop yields by many folds. The organic matter (OM) of the studied tea-estate varied from $0.37 \%$ to $1.93 \%$. Organic matter content is found to vary with topographic positions. Hill base soils of $0-23 \mathrm{~cm}$ depth contain the highest percentage of organic matter, while that in the substratum soils $(46-91 \mathrm{~cm})$ of all topographic positions is lower than the other depths. The variation of this parameter for different soil depths follows the order: Top soil $(0-23 \mathrm{~cm})>$ Sub soil $(23-46 \mathrm{~cm})>$ Substratum soil $(46-91 \mathrm{~cm}$ ) (Table 2). The percent of OM content of the soils of Rungicherra tea-estate varied from $1.37 \sim 2.14$ [21] and this range is higher than that in the present studied tea-garden. Chaudhury and Shome [29] reported the highest value 2.58 $\%$ of organic matter content for Udnacherra tea-estate of the same district, whereas, Islam et al. [31] reported the highest value of $2.28 \%$ for Chandra soils of Madhupur Tract.

Active acidity of the soils was found to range from 4.13 to 5.82. These values indicate that the studied soils are moderately acidic in nature. In the prevailing acidic condition, the availability of nutrients to tea plants will be hampered due to aluminum toxicity [32]. This may be one of the causes of low yield of tea. The observed active acidity values of some collected samples were not found to lie within the optimum $\mathrm{pH}$ range $4.5-5.8$ for tea cultivation [33]. Sub-soils $(23-46 \mathrm{~cm})$ of the hill-base show the lowest $\mathrm{pH}$ (4.13). This value is closer to the lower limit of the optimum range indicating additional lime treatment is required to decrease the soil acidity. We reported earlier, a narrower $\mathrm{pH}$ range 4.33-5.01 and 3.85-5.13 for the Rungicherra tea-estate [19] of Moulvibazar district and Rangapani tea-estate [23] of Chittagong district, respectively. 
Soil $\mathrm{pH}$ measured using $\mathrm{CaCl}_{2}$ solution has some advantage over that using $\mathrm{H}_{2} \mathrm{O}$, because $\mathrm{CaCl}_{2}$ can minimize suspension effect and equalize salt contents in the soil [34]. In an acid soil, most of the $\mathrm{H}^{+}$ions present are absorbed by the soil (reserve acidity). Relatively higher $\mathrm{pH}$ values at the surface layer across the studied area may be linked to the larger amounts of organic matter in the top soil [35] and indicate that surface layer was accompanied with organic composts, leaves and other natural components. Reserve acidity is associated with the soil phase and it is equal to all titratable acidity. It represents the buffer capacity of a soil. Reserve acidity $\left(\mathrm{pH}\right.$ in $\left.\mathrm{CaCl}_{2}\right)$ of the soil samples was found to range from 3.46 to 4.84 . Ahmed et al. [20] observed a little narrower reserve acidity value (3.66 to 4.06) for Rungicherra tea-estate of Moulvibazar district, whereas, Islam et al. [23] reported an almost similar range of reserve acidity (3.37-4.31) value for Rangapani tea-estate of Chittagong district. The reserve acidity of soil is always higher than the active acidity, because in an acid soil, the cation exchange sites of the soil absorb most of the $\mathrm{H}^{+}$ions present in soil. Active acidity and reserve acidity are found to vary significantly (Table 1 and 2) and these variations may be due to difference in washing, fertilizer application, lime treatment, decay of plant residues etc.

Table 1. Effect of topography on sand, silt, clay content, organic matter, active acidity $\left(\mathrm{pH}\right.$ in $\mathrm{H}_{2} \mathrm{O}$ ), reserve acidity ( $\mathrm{pH}$ in $\mathrm{CaCl}_{2}$ ), and cation exchange capacity (CEC) of soils of $\mathrm{M}$. R. Khan tea-estate.

\begin{tabular}{|c|c|c|c|c|c|c|}
\hline \multirow{2}{*}{ Parameter } & \multicolumn{3}{|c|}{ Topography } & \multirow{2}{*}{$\begin{array}{l}\text { F-statistics } \\
\text { @ } \mathrm{df}=2\end{array}$} & \multirow{2}{*}{ LSD0.05 } & \multirow{2}{*}{ Probability } \\
\hline & Hill-Base & Hill-Slope & Hill-Top & & & \\
\hline Sand $\%$ & $64.64 \pm 3.21 \mathrm{a}$ & $65.06 \pm 2.39 b$ & $67.26 \pm 2.67 \mathrm{c}$ & 4.6873 & 1.8522 & 0.0137 \\
\hline Silt $\%$ & $17.08 \pm 1.96 \mathrm{a}$ & $17.08 \pm 1.76 b$ & $15.83 \pm 1.48 \mathrm{c}$ & 3.1203 & 1.1613 & 0.0530 \\
\hline Clay $\%$ & $18.27 \pm 2.59 \mathrm{a}$ & $17.86 \pm 2.23 \mathrm{a}$ & $16.91 \pm 2.86 \mathrm{a}$ & 1.4469 & ------ & 0.2452 \\
\hline $\mathrm{OM} \%$ & $1.25 \pm 0.35 \mathrm{a}$ & $0.96 \pm 0.47 b$ & $0.90 \pm 0.54 \mathrm{c}$ & 17.3596 & 0.1261 & 0.0000 \\
\hline $\mathrm{pH}$ in $\mathrm{H}_{2} \mathrm{O}$ & $4.54 \pm 0.18 \mathrm{a}$ & $4.68 \pm 0.33 b$ & $4.78 \pm 0.46 c$ & 2.4821 & ----- & 0.0940 \\
\hline $\mathrm{pH}$ in $\mathrm{CaCl}_{2}$ & $3.86 \pm 0.09 \mathrm{a}$ & $3.88 \pm 0.19 \mathrm{a}$ & $3.98 \pm 0.37 \mathrm{a}$ & 1.3824 & ----- & 0.2606 \\
\hline $\mathrm{CEC}\left(\mathrm{cmol} \mathrm{Kg}{ }^{-1}\right)$ & $20.77 \pm 2.92 \mathrm{a}$ & $17.76 \pm 1.87 b$ & $14.96 \pm 2.49 \mathrm{c}$ & 26.9339 & 1.5881 & 0.0000 \\
\hline
\end{tabular}

Note: Values followed by same letter are not significant at 0.05 LSD

Table 2. Effect of depth on sand, silt, clay content, organic matter, active acidity $\left(\mathrm{pH}\right.$ in $\mathrm{H}_{2} \mathrm{O}$ ), reserve acidity ( $\mathrm{pH}$ in $\mathrm{CaCl}_{2}$ ), and cation exchange capacity (CEC) of soils of $\mathrm{M}$. R. Khan tea-estate.

\begin{tabular}{lllllll}
\hline \multirow{2}{*}{ Parameter } & \multicolumn{3}{c}{ Depth $(\mathrm{cm})$} & \multicolumn{1}{c}{ F-statistics } & \multirow{2}{*}{ LSD0.05 } & \multirow{2}{*}{ Probability } \\
\cline { 2 - 6 } & \multicolumn{1}{c}{$0-23$} & \multicolumn{1}{c}{$23-46$} & \multicolumn{1}{c}{$46-91$} & @ df=2 & & \\
\hline Sand \% & $65.61 \pm 2.26 \mathrm{a}$ & $66.42 \pm 3.05 \mathrm{a}$ & $64.93 \pm 3.44 \mathrm{a}$ & 1.3035 & ---- & 0.2808 \\
Silt \% & $17.22 \pm 1.89 \mathrm{a}$ & $16.52 \pm 1.52 \mathrm{a}$ & $16.25 \pm 1.96 \mathrm{a}$ & 1.5023 & ---- & 0.2327 \\
Clay \% & $17.17 \pm 2.29 \mathrm{a}$ & $17.06 \pm 2.80 \mathrm{~b}$ & $18.82 \pm 2.40 \mathrm{c}$ & 2.8405 & 1.6662 & 0.0681 \\
$\mathrm{OM} \mathrm{\%}$ & $1.61 \pm 0.22 \mathrm{a}$ & $0.88 \pm 0.30 \mathrm{~b}$ & $0.63 \pm 0.18 \mathrm{c}$ & 132.6767 & 0.1261 & 0 \\
$\mathrm{pH} \mathrm{in} \mathrm{H}_{2} \mathrm{O}$ & $4.86 \pm 0.37 \mathrm{a}$ & $4.63 \pm 0.38 \mathrm{~b}$ & $4.50 \pm 0.20 \mathrm{c}$ & 5.7878 & 0.2128 & 0.0055 \\
$\mathrm{pH} \mathrm{in} \mathrm{CaCl}_{2}$ & $4.06 \pm 0.29 \mathrm{a}$ & $3.86 \pm 0.24 \mathrm{~b}$ & $3.80 \pm 0.13 \mathrm{c}$ & 6.0165 & 0.1545 & 0.0046 \\
$\mathrm{CEC}\left(\mathrm{cmol} \mathrm{Kg}^{-1}\right)$ & $18.96 \pm 3.26 \mathrm{a}$ & $17.23 \pm 4.24 \mathrm{~b}$ & $17.31 \pm 2.32 \mathrm{c}$ & 3.0882 & 1.5881 & 0.0546 \\
\hline
\end{tabular}

Note: Values followed by same letter are not significant at 0.05 LSD

Cation exchange capacity (CEC) of the studied soils was found to vary from 11.42 to $24.86 \mathrm{cmol} \mathrm{Kg}^{-1}$. The lowest value of CEC was found for the sub soils $(23-46 \mathrm{~cm})$ of hill 
base, while the Hill-top soils of the same depth contain the highest value of cation exchange capacity. The lower CEC favor the better growth of tea and that was observed in the hill-base. The reason may be soil $\mathrm{pH}$ decreases with decreasing CEC in the studied soil and thereby tea plants grow better in soil with low $\mathrm{pH}$. Cation exchange capacity mainly depends on the organic matter of the soil. Hossain et al. [35] reported CEC of soils of Satgoan, Baraora and Kurmah tea-estates and observed a wider range of variation in CEC (5.15 to $33.25 \mathrm{cmol} \mathrm{Kg}^{-1}$ ). Recently, we have reported [20] the CEC (4.57 to 16.07 $\mathrm{cmol} \mathrm{Kg}{ }^{-1}$ ) of Rungicherra tea-estate of Moulvibazar district and the CEC (6.6 to $33 \mathrm{cmol}$ $\mathrm{Kg}^{-1}$ ) of Rangapani tea-estate [23] of Chittagong district. The higher CEC in surface soil might be associated with higher amount of organic carbon [37] and $\mathrm{pH}$ [38] in surface layers. The variation of CEC with topography as well as depth is remarkable for M. R. Khan tea-estate and are found to follow the following sequences irrespective of their magnitudes of variations: (i) Hill-top > Hill-slope > Hill-base; (ii) Top soil $(0-23 \mathrm{~cm})>$ Substratum soil $(46-91 \mathrm{~cm})>$ Sub soil $(23-46 \mathrm{~cm})$.

The experimental data for sand, silt and clay content, organic matter content, active acidity, reserve acidity, and cation exchange capacity have been analyzed statistically by using two-way ANOVA to see the effect of topography as well as depth on the measured parameters. The values of $\mathrm{F}$ statistics, probability (applicability of null hypothesis) and least significant difference at $95 \%$ confidence level (LSD 0.05) were calculated. Statistically analyzed data and the F values have been presented in Table 1 and 2. For different topographic positions $\mathrm{F}$ values are found $2.4821,1.3824$ and 1.4469 , respectively for active acidity, reserve acidity and clay content. These values of $F$ with high probability values indicate that topographic variations have almost no effect on active acidity, reserve acidity and clay content i.e., null hypothesis is valid for these parameters. But the values of $\mathrm{F}$ for sand, silt, organic matter and CEC due to topographic variations are found $4.6873,3.1203,17.3596$ and 26.9339, respectively. These values of $F$ for sand and silt content are significant at extremely low levels and F values for OM and CEC are significant at high levels. These values indicate that the topographic variations have significant effect on sand, silt, OM and CEC.

While working with different soil depths it has been found that $\mathrm{F}$ values for clay content, organic matter content, active acidity, reserve acidity, and CEC are 2.8405, $132.6767,5.7878,6.0165$ and 3.0882, respectively. These values of $F$ are significant at less than $6.81 \%$ level, thus indicating clay content, organic matter content, active acidity, reserve acidity and cation exchange capacity significantly varied with soil depths. On the other hand, the observed values of $F$ for sand (1.3035) and silt (1.5023) with respective probability values 0.2808 and 0.2327 , indicates that sand and silt does not vary significantly with soil depths.

\section{Conclusion}

Textural class of the maximum soil samples is sandy loam. Clay content and the cation exchange capacity of the soils are satisfactory. Active acidity of maximum soil samples is 
very near to the lower limit of optimum range for tea cultivation. So, lime/dolomite treatment with proper drainage and shade is suggested for improving the active acidity level to get better yield and quality of tea.

\section{Acknowledgment}

The authors are thankful to the soil science division of Forest Research Institute, Chittagong, Bangladesh for supporting necessary laboratory facilities to conduct this research.

\section{References}

1. A. P. Hamblin and D. B. Davies, Soil Sci. 28, 11 (1977). http://dx.doi.org/10.1111/j.1365-2389.1977.tb02291.x

2. D. Curtin, H. P. W. Rostad, and P.M. Huang, Can. J. Soil Sci. 64, 545 (1984). http://dx.doi.org/10.4141/cjss84-055

3. J. O. Reuss, P. M. Walthall, E. C. Roswall, and R. W. E. Hopper, Soil Sci. Soc. Am. J. 54, 374 (1990). http://dx.doi.org/10.2136/sssaj1990.03615995005400020013x

4. R. L. Aitken, Aus. J. Soil Res. 30, 119 (1992). http://dx.doi.org/10.1071/SR9920119

5. D. Curtin and H. P. W. Rostad, Can. J. Soil Sci. 77, 621 (1997). http://dx.doi.org/10.4141/S97-015

6. G. Matschonat and R.Vogt, Eur. J. Soil Sci. 48, 163 (1997). http://dx.doi.org/10.1046/j.1365-2389.1997.00103.x

7. R. P. Griffiths, M. D. Madritch, and A. K. Swanson, For. Eco. Manag. 257, 1 (2009). http://dx.doi.org/10.1016/j.foreco.2008.08.010

8. M. Akhtaruzzaman, K. T. Osman, and S. M. S. Haque, J. For. Environ. Sci. 31, 14 (2015).

9. T. J. Moore and R. H. Loeppert, Soil Sci. Soc. Am. J. 51, 908 (1987). http://dx.doi.org/10.2136/sssaj1987.03615995005100050029x

10. A. W. West, G. P. Sparling, C. W. Feltham, and J. Reynolds, Aus. J. Soil Res. 30, 209 (1992). http://dx.doi.org/10.1071/SR9920209

11. D. T. Strong, P. W. G. Sale, and K. R. Helyar, Aus. J. Soil Res. 35, 565 (1997). http://dx.doi.org/10.1071/S96055

12. R. L. Haney, A. J. Franzluebbers, F. M. Hons, and D. A. Zuberer, Can. J. Soil. Sci. 79, 529 (1999). http://dx.doi.org/10.4141/S99-011

13. S. Gogoi, M. K. Bhuyan, and R. M. Karmakar, J. Ind. Soc. Soil Sci. 51, 252 (2003).

14. B. N. Ghosh, J. Ind. Soc. Soil Sci. 51, 301 (2003).

15. C. Chen, L. Condron, M. Davis, and R. Sherlock, Plant and Soil 220, 151 (2000). http://dx.doi.org/10.1023/A:1004712401721

16. N. J. McKenzie and P.J. Ryan, Geoderma 89, 67 (1999). http://dx.doi.org/10.1016/S0016-7061(98)00137-2

17. H. Gao, L. Qiu, Y. Zhang, L. Wang, X. Zhang, and J. Cheng, Soil Res. 51, 406 (2013). http://dx.doi.org/10.1071/SR12250

18. S. W. Buol, R. J. Southard, R. C. Graham, and P. A. McDaniel, Soil Genesis and Classification (Wiley Blackwell, 2011). http://dx.doi.org/10.1002/9780470960622

19. P. McDaniel, A. Falen, G. Bathke, S. Buol, and D. Cassel, Soil Sci. Soc. Am. J. 56, 1211 (1992). http://dx.doi.org/10.2136/sssaj1992.03615995005600040034x

20. M. S. Ahmed, M. R. Zamir, and A. F. M. Sanaullah, Inter. J. Agri. Biol. 8, 89 (2006).

21. M. S. Ahmed, M. R. Zamir, and A. F. M. Sanaullah, Pak. J. Anal. Chem. 6, 10 (2005).

22. M. S. Ahmed, M. M.H. Shahin, and A. F. M. Sanaullah, Pak. J. Anal. Chem. 6, 59 (2005). 
23. M. N. Islam and A. F. M. Sanaullah, J. Sci. Res. 3, 683 (2011). http://dx.doi.org/10.3329/jsr.v3i2.7012

24. P. R. Day, Particle Size Distribution and Particle Size Analysis. In: Black, C. A. (ed.) Methods of Soil Analysis. American Society of Agronomy (Madison, Wisconsin, USA. 1965) pp. 545.

25. A. Walkley and I. Black, Soil Sci. 37, 29 (1934). http://dx.doi.org/10.1097/00010694-193401000-00003

26. M. L. Jackson, Soil Chemical Analysis (Prentice Hall of India, Pvt. Ltd., New Delhi, 1973) pp. 498.

27. K. A. Armson, Forest Soils: Properties and Processes (University of Toronto Press, Toronto, 1977) pp. 390

28. C. A. Black, Methods of Soil Analysis Part II, American Society of Agronomy, Inc. Madison (Wisconsin, USA, 1965) pp. 894.

29. S. H. Chaudhury and K. A. Hasan, Tea J. Bang. 10, 3 (1974).

30. S. H. Chaudhury and K. M. Shome, Tea J. Bang. 14, 12 (1978).

31. A. K. M. N. Islam, A. J. M. S. Karim, M. A. Rahman, M. M. Begum, and K. M. Khalequzzaman, Bang. J. Agr. Res. 27, 553 (2002).

32. E. Abate, S. Hussien, M. Laing and F. Mengistu, Afri. J. Agri. Res. 8, 711 (2013).

33. S. H. Chaudhury, Tea J. Bang. 14, 2 (1978).

34. A. Al-Busaidi, P. Cookson, and T. Yamamoto, Aus. J. Soil Res. 43, 541 (2005). http://dx.doi.org/10.1071/SR04102

35. G. S. P. Ritchie and P. J. Dolling, Aus. J. Soil Res. 23, 569 (1985). http://dx.doi.org/10.1071/SR9850569

36. M. F. Hossain, A. Islam, W. Islam, and S. Rahaman, Tea J. Bang. 24, 8 (1988).

37. Y.G. Zhang, Z. W. Xu, D. M. Jiang, and Y. Jiang, J. Arid Land 5, 42 (2013).

38. E. C. Bortoluzzi, D. Tessier, and D. S. Rheinheimer, Eur. J. Soil Sci. 57, 356 (2006). http://dx.doi.org/10.1111/j.1365-2389.2005.00746.x 